\title{
Bison and bovine rectoanal junctions exhibit similar cellular architecture and Escherichia coli 0157 adherence patterns
}

\author{
Indira T Kudva ${ }^{*}$ and Judith A Stasko²
}

\begin{abstract}
Background: Escherichia coli O157 (E. coli O157) has been isolated from bison retail meat, a fact that is important given that bison meat has been implicated in an E. coli O157-multistate outbreak. In addition, E. coli O157 has also been isolated from bison feces at slaughter and on farms. Cattle are well documented as E. coli O157 reservoirs, and the primary site of E. coli 0157 persistence in such reservoirs is the rectoanal junction (RAJ), located at the distal end of the bovine gastrointestinal tract. Since bison and cattle share many genetic similarities manifested as common lineage, susceptibility to infection and the nature of immune responses to infectious agents, we decided to evaluate whether the RAJ of these animals were comparable both in terms of cellular architecture and as sites for adherence of E. coli O157. Specifically, we compared the histo-morphologies of the RAJ and evaluated the E. coli O157 adherence characteristics to the RAJ squamous epithelial (RSE) cells, from these two species.

Results: We found that the RAJ of both bison and cattle demonstrated similar distribution of epithelial cell markers villin, vimentin, cytokeratin, E-cadherin and N-cadherin. Interestingly, N-cadherin predominated in the stratified squamous epithelium reflecting its proliferative nature. E. coli 0157 strains $86-24 \mathrm{Sm}^{\mathrm{R}}$ and EDL 933 adhered to RSE cells from both animals with similar diffuse and aggregative patterns, respectively.

Conclusion: Our observations further support the fact that bison are likely 'wild life' reservoirs for E. coli O157, harboring these bacteria in their gastrointestinal tract. Our results also extend the utility of the RSE-cell assay, previously developed to elucidate E. coli O157-cattle RAJ interactions, to studies in bison, which are warranted to determine whether these observations in vitro correlate with those occurring in vivo at the RAJ within the bison gastrointestinal tract.
\end{abstract}

Keywords: O157:H7, Bovine, Bison, Tissue, Epithelia, Markers, Adherence

\section{Background}

Sixty million bison also referred to as buffalo, roamed North America before 1492 [1-3]. These comprised both the plains bison (Bison bison bison) found along the Great Plains, and the wood bison (Bison bison athabascae) restricted to the Northwest Territories and Alberta. However, by mid-1880, these animals became nearly extinct; their numbers reduced to 750 as a result of indiscriminate hunting for hides, meat and sport. Private herds held by ranchers and national parks enabled restoration of the bison population which were recorded at $\sim 1$ million in

\footnotetext{
* Correspondence: Indira.Kudva@ars.usda.gov

${ }^{1}$ Food Safety and Enteric Pathogens Research Unit, National Animal Disease Center, Agricultural Research Service, U.S. Department of Agriculture, Ames, IA 50010, USA

Full list of author information is available at the end of the article
}

2009 [1-3]. Although no longer listed as endangered, bison are still treated as a "conservation" species because of their relative low numbers, ongoing breeding and selection practices [1-3].

Bison are phylogenetically related to the European bison (Bison bonasus), African (Syncerus caffer) and Asian buffaloes (Bubalus arnee, Bubalus bubalis), yak (Bos grunniens, Bos mutus) and domesticated cattle (Bos taurus) [1,4]. Bison and cattle share several innate immunological features, some of which may actually help this animal combat shared diseases, most common of which are brucellosis, tuberculosis, anthrax, and malignant catarrhal fever [5-9]. While bison may acquire these infections in the wild, increased exposure has been associated with co-mingling domesticated ruminants [8-10]. Additionally, a renewed interest in the low cholesterol 
and high protein bison meat has resulted in these animals being actively farmed, thereby enabling transmission of disease agents among bison and other livestock $[7,11]$. Bison and cattle appear to share several gastrointestinal microflora, with the predominating gram-negative bacteria in fecal samples being Escherichia coli (E. coli) [12]. Studies evaluating the fecal $E$. coli serotypes indicate that while E. coli O157:H7 (E. coli O157) may not be consistently isolated from the gastrointestinal tracts of wild bison, it is prevalent in $17-83 \%$ of farmed bison much like its recovery from farmed Asian water buffaloes [12-14].

E. coli $\mathrm{O} 157$ are important foodborne, human pathogens that have been implicated in several outbreaks; an estimated 63,153 illnesses, 2,138 hospitalizations and 20 deaths occur annually in the United States [15-17]. Human disease ranges from self-limiting watery diarrhea to debilitating bloody diarrhea that can advance into often-fatal secondary sequelae in susceptible patients [18-20]. The annual cost of these human Shiga Toxinproducing E. coli (STEC) infections range anywhere from $\$ 26$ to $\$ 211,084$, depending on the severity of the disease caused [15,17,21-23]. Cattle are the primary reservoirs for E. coli $\mathrm{O} 157$ and hence, food products derived from these ruminants contaminated with E. coli O157containing manure are the major sources of infection [18-20], resulting in large scale recalls of contaminated meat and produce. These recalls result in losses of up to millions of dollars annually for the meat industry [21,22]. Adding to the complexity of this situation is crosscontamination of food from sources other than cattle, many of which remain unidentified, unregulated or under voluntary federal inspection $[3,11,14,20,24]$. Bison is one such source; E. coli O157 has been isolated from bison retail meat, with variable levels of contamination $[3,25,26]$. Recently, E. coli O157-contaminated ground bison was implicated in a multi-state outbreak, resulting in the recall of $66,000 \mathrm{lbs}$ of this meat $[3,24,27]$. Reinstein et al., reported a $42.1 \%$ E. coli $\mathrm{O} 157$ prevalence in bison feces at slaughter and the high recovery in the pasturefed bison was correlated with similar prevalence in cattle fed forage diets [28]. Given the recovery of E. coli O157 from bison (animal and meat) and its similarity to cattle, several studies are underway to determine E. coli O157 colonization patterns in this animal [25,26,28,29]. The rectoanal junction (RAJ) is the primary site of $E$. coli O157 persistence in cattle gastrointestinal tracts, but a similar observation has not been conclusively made with bison [28,30-32]. Hence, in this study, we (i) examined the cellular architecture via comparative histomorphological studies of bison and bovine rectoanal junctions, (ii) determined whether E. coli O157 could adhere to squamous epithelial (RSE) cells derived from bison rectoanal junctions, and (iii) compared the patterns of E. coli $\mathrm{O} 157$ adherence to RSE cells from both bison and bovine rectoanal junctions. Our results indicate that bison are likely reservoirs of this human pathogen; it also extends the utility of the RSE cell adherence assay for confirmatory studies of the same.

\section{Methods}

\section{Animals and bacteria}

Eight cattle and five bison, included in unrelated experiments at the National Animal Disease Center (NADC), Ames, IA, under the approval of the NADC-Animal Care and Use Committee, were sampled in this study [32-34]. Six of the eight cattle had been experimentally inoculated with E. coli O157 [32-34]; a streptomycinresistant derivative of the clinical $E$. coli $\mathrm{O} 157$ strain 86-24 (86-24. Sm ${ }^{\mathrm{R}}$; NADC \# 5570). The remaining two cattle were part of the 'blood donor' group that is routinely maintained at the NADC, and not exposed to E. coli O157. The cattle were of various breeds, ranged in age from 4 months to 8 years, and were fed according to their age, a post-weaning diet (two-thirds grain and onethird hay), or the NADC maintenance diet (corn silage, grass hay, 520 pellets (Purina Mills, St. Louis, MO), protein supplements). The five bison were approximately 2 years in age and fed prairie hay and 521 pellets (Purina Mill, St. Louis, MO), and never inoculated with E. coli O157. All animals had ad-libitum access to water. Rectoanal junctions (RAJ) tissue samples were recovered from all these animals at necropsy. The E. coli O157 strains 86-24 $\mathrm{Sm}^{\mathrm{R}}$ and EDL 933 [32-34] were used in the RSE cell-adherence assays.

\section{Tissue sampling and histology}

Each RAJ tissue sample, dissected out of both bison and bovine gastrointestinal tracts, was divided into three parts to process using different techniques. One part of the RAJ was opened and its mucosal surface placed against a piece of liver from the same animal to support and maintain the structural integrity of this surface. The tissue assembled in this manner was then placed in the OCT solution (Optimal Cutting Temperature solution Tissue-Tek, Sakura Finetek, Torrance, CA) and flashfrozen in isopentane on dry ice-ethanol bath before storing at $-80^{\circ} \mathrm{C}$ [33]. The frozen tissue was sectioned in the laboratory using the Leica CM 1900 cryostat (Leica Microsystems, Buffalo Grove, IL), and the sections collected on Probe On + slides (Thermo Fisher Scientific, Pittsburgh, PA) were air-dried and fixed in 95\% ethanol before staining $[33,35]$. The second part of the RAJ was fixed in 10\% formalin 24-48 h, embedded in paraffin and sections prepared and processed on Probe On + slides as described before [32]. The third piece was rinsed with sterile phosphate buffered saline (PBS) and transported to the laboratory in Dulbecco's Modified Eagle Medium -No Glucose (DMEM-NG; Invitrogen, 
Carlsbad, CA) supplemented with $2.5 \%$ fetal bovine serum (Thermo Scientific HyClone, Logan, UT), $100 \mu \mathrm{g} / \mathrm{ml}$ streptomycin- $100 \mathrm{U} / \mathrm{ml}$ penicillin (Pen-Strep; Invitrogen) and $50 \mu \mathrm{g} / \mathrm{ml}$ gentamicin (Invitrogen), to harvest the RAJ squamous epithelial (RSE) cells as described previously [33].

\section{Staining}

\section{(i) Immunofluorescent staining}

Ethanol-fixed slides were processed for immunofluorescent staining using a previously described protocol [33]. Briefly, the slides were washed in PBS at room temperature and blocked with 5\% normal goat serum in $\mathrm{PBS}\left(37^{\circ} \mathrm{C}\right.$ for $\left.30 \mathrm{~min}\right)$ prior to incubation with selected primary antibody diluted in $\operatorname{PBS}\left(37^{\circ} \mathrm{C}\right.$ for $\left.1 \mathrm{~h}\right)$. Subsequently, slides were washed with $\mathrm{PBS}$ at room temperature and incubated with the corresponding secondary antibody diluted in 5\% normal goat serum in PBS $\left(37^{\circ} \mathrm{C}\right.$ for $\left.1 \mathrm{~h}\right)$. Then the slides were washed, air dried in the dark and coverslipped with Prolong Gold antifade reagent containing the DNA stain 4', 6'- diamidino-2-phenylindole (DAPI; Invitrogen, Carlsbad, CA). When required, slides were permeabilized with $0.1 \%$ Triton X-100 prior to staining with Phalloidin as recommended by manufacturer (Life Technologies, Grand Island, NY). Primary and the corresponding secondary antibodies used for immunofluorescent staining are shown in Table 1. All slides were analyzed using the Nikon Eclipse E800 fluorescence microscope (Nikon Instruments Inc., Elgin, IL) equipped with fluorescence illumination and digital imaging. Digital images were obtained using a Digital sight DS-Rilcamera (Nikon) and acquired using the NIS-Elements imaging software (Nikon). Controls used to verify specificity of antibody interactions included slides with no bacteria or staining with unrelated fluorescence-tagged antibodies [33].

\section{(ii) Immunoperoxidase staining}

Indirect immunoperoxidase (horseradish peroxidase) staining was done at room temperature, on formalin-fixed paraffin embedded (FFPE) tissue section slides, after de-paraffinization using standard protocols [36]. The slides were washed with tris-buffered saline (TBS), and processed as described previously [33]. Briefly, slides were blocked with the universal block (KPL, Gaithersburg, $\mathrm{MD}$ ) and 5\% normal rabbit serum (NRS) in TBS, and subsequently incubated ( $2 \mathrm{hr}$ ) with goat anti-O157 (diluted in NRS; KPL) primary antibody. After three washes with TBS, the slides were incubated with biotinylated rabbit anti-goat (diluted in NRS) secondary antibody (30 min; Vector Laboratories, Burlingame, CA) which was traced with the avidin-tracer (horseradish peroxidase)-complex solution (BioStain Super ABC Kit, Biomeda Corporation, Foster City, CA.), an enhancer solution prepared with $0.25 \%$ Brij (Thermo Fisher Scientific, Pittsburgh, PA.) in TBS, and the diaminobenzidine hydrochloride (DAB) - peroxide solution. Next, the slides were counterstained with hematoxylin (Gills No. 2; Sigma-Aldrich, St. Louis, MO), washed, dehydrated in $95 \%$ and 100\% ethanol before coverslipping in a 1:1 solution of permount and xylene (Molecular Devices, Inc., Sunnyvale, CA).

\section{RSE cell adherence assay}

Adherence of E. coli O157 to bovine RSE cells was previously demonstrated and developed into an adherence assay in our laboratory [33,34]. In the present study, the assay was used to compare interactions of E. coli $\mathrm{O} 157$ with RSE cells obtained from bison versus bovine RAJ. Each of the RSE adherence assays was conducted in eight technical and two biological replicates as described previously [33,34]. Briefly, RSE cells were washed and resuspended in DMEM-NG (Invitrogen) with $2.5 \% \mathrm{D}+$ Mannose to a final concentration of $10^{5}$ cells $/ \mathrm{ml}$. Bacterial

Table 1 Antibodies used for immunofluorescence staining

\begin{tabular}{|c|c|c|c|}
\hline Primary/target & Source & Secondary & Source \\
\hline $\begin{array}{l}\text { Mouse anti- (PAN) cytokeratins/Eukaryotic } \\
\text { cytoskeletal protein }\end{array}$ & AbD Serotec, Raleigh, NC & $\begin{array}{l}\text { Alexa Fluor } 594 \text { (red) labeled goat anti-mouse } \\
\operatorname{lgG}\left(\mathrm{H}+\mathrm{L}_{;} \mathrm{F}(\mathrm{ab})_{2} \text { fragment) }\right.\end{array}$ & $\begin{array}{l}\text { Life Technologies, } \\
\text { Grand Island, NY }\end{array}$ \\
\hline $\begin{array}{l}\text { Mouse anti- villin/Eukaryotic brush } \\
\text { border protein }\end{array}$ & $\begin{array}{l}\text { Chemicon, EMD Millipore, } \\
\text { Billerica, MA }\end{array}$ & $\begin{array}{l}\text { Alexa Fluor } 488 \text { (green) labeled goat anti-mouse } \\
\operatorname{lgG}\left(\mathrm{H}+\mathrm{L} ; \mathrm{F}(\mathrm{ab})_{2}^{\prime}\right)_{2} \text { fragment) }\end{array}$ & $\begin{array}{l}\text { Life Technologies, } \\
\text { Grand Island, NY }\end{array}$ \\
\hline $\begin{array}{l}\text { Mouse anti-vimentin/Eukaryotic mesenchymal } \\
\text { cell protein }\end{array}$ & Abcam, Cambridge, MA & $\begin{array}{l}\text { Alexa Fluor } 488 \text { (green) labeled goat anti-mouse } \\
\text { lgG }\left(\mathrm{H}+\mathrm{L} ; \mathrm{F}(\mathrm{ab})_{2}\right)_{2} \text { fragment) }\end{array}$ & $\begin{array}{l}\text { Life Technologies, } \\
\text { Grand Island, NY }\end{array}$ \\
\hline $\begin{array}{l}\text { Rabbit anti- N-cadherin/Eukaryotic } \\
\text { transmembrane glycoprotein }\end{array}$ & Abcam, Cambridge, MA & $\begin{array}{l}\text { Alexa Fluor } 594 \text { (red) labeled goat anti-rabbit } \\
\operatorname{lgG}\left(\mathrm{H}+\mathrm{L} ; \mathrm{F}\left(\mathrm{ab}^{\prime}\right)_{2} \text { fragment) }\right.\end{array}$ & $\begin{array}{l}\text { Life Technologies, } \\
\text { Grand Island, NY }\end{array}$ \\
\hline $\begin{array}{l}\text { Rat anti- E-cadherin/Eukaryotic transmembrane } \\
\text { glycoprotein }\end{array}$ & Novus Biologicals, Littleton, CO & $\begin{array}{l}\text { Alexa Fluor } 488 \text { (green) labeled goat anti-rat } \\
\text { lgG }\left(\mathrm{H}+\mathrm{L} ; \mathrm{F}\left(\mathrm{ab} \mathrm{b}_{2}\right)_{2} \text { fragment) }\right.\end{array}$ & $\begin{array}{l}\text { Life Technologies, } \\
\text { Grand Island, NY }\end{array}$ \\
\hline $\begin{array}{l}\text { Alexa Fluor } 594 \text { (red) labeled phallodin/ } \\
\text { Eukaryotic microfilament protein actin }\end{array}$ & $\begin{array}{l}\text { Life Technologies, Grand } \\
\text { Island, NY }\end{array}$ & - & - \\
\hline- & - & $\begin{array}{l}\text { FITC (green) labeled goat anti-O157/targets } \\
\text { surface antigen of E. coli O157 bacteria }\end{array}$ & $\begin{array}{l}\text { KPL, Gaithersburg, } \\
\text { MD }\end{array}$ \\
\hline
\end{tabular}


pellets from overnight cultures in DMEM-Low Glucose $\left(\mathrm{OD}_{600} \sim 0.5-0.7\right)$ were washed and mixed with RSE cell suspensions to a final bacteria: cell ratio of 10:1 and incubated at $37^{\circ} \mathrm{C}, 110 \mathrm{rpm}$, for $4 \mathrm{~h}$. Subsequently, the mixture was pelleted, washed, reconstituted in $100 \mu$ l distilled water and eight- $2 \mu$ drops of this placed on Polysine (Thermo Scientific Pierce, Logan, UT) slides. Quenched, dried, and 95\% ethanol-fixed slides were then stained with 1\% toluidine blue, or fluorescence-tagged antibodies that target E. coli $\mathrm{O} 157$ and the RSE cell cytokeratins as described previously (Table 1; 33). E. coli O157 adherence patterns on RSE cells were recorded as either diffuse or aggregative (clumps) for all interactions that involved direct association with the cells, as described previously [33,34]. Bacterial adherence was quantitated and the average percents with standard error of means between trials was calculated using the GraphPad Prism5 software, as before $[33,34]$. If more than $50 \%$ of RSE cells had $>10$ bacteria attached, the adherence was recorded as strongly positive. For $>50 \%$ RSE cells with 1-10 adherent bacteria, the adherence was recorded as moderately positive. For less than 50\% RSE cells with 1-5 adherent bacteria, the result was recorded as nonadherent.

\section{Transmission Electron Microscopy (TEM)}

\section{(i) Tissue preparation}

Portions of FFPE tissues were processed using a standard protocol $[37,38]$. After removal of paraffin, the samples were put through changes of xylene and immersed in graded alcohol solutions before being fixed with $2.5 \%$ glutaraldehyde for $1-2 \mathrm{~h}$, and transferred to PBS. The samples were then post-fixed in $1 \%$ osmium tetroxide, processed through another series of graded alcohols, embedded in Eponate $12^{\mathrm{mm}}$ resin (Ted Pella, Redding, CA) and polymerized at $60^{\circ} \mathrm{C}$, overnight $[37,38]$.

\section{(ii) RSE cells preparation}

An 'agar-block' technique was devised that would enable capturing the RSE cells and processing them like tissue samples. The RSE cells (bison/bovine), with and without adhering E. coli O157, were fixed with 2.5\% glutaraldehyde in $0.1 \mathrm{M}$ cacodylate buffer, overnight. Next, the suspension was centrifuged; the resulting pellet was placed into molten $2 \%$ agar, and allowed to set in block-molds. The agar-blocks were then postfixed in $1 \%$ osmium tetroxide, processed and embedded in the Eponate $12^{\mathrm{TM}}$ resin as described above $[37,38]$.

\section{(iii) Negative staining}

Negative staining [39] of RSE cells- E. coli O157 suspensions was done as an initial screen to verify eukaryotic cell structure and presence of bacteria before proceeding with the agar-block preparation. Briefly, equal volumes of sample and $2 \%$ phosphotungstic acid at $\mathrm{pH} 7.0$ were mixed and placed on formvar coated copper grids for $3 \mathrm{~min}$. The excess liquid was wicked, grids air-dried and visualized on the FEI Tecnai ${ }^{\mathrm{Ts}} \mathrm{G}^{2}$ Biotwin electron microscope.

\section{(iv) Immunogold staining}

Thin sections of the Eponate $12^{\mathrm{Tm}}$ resin blocks embedded with tissue or RSE cells with E. coli O157 were cut $70 \mathrm{~nm}$ thick on the Leica UC7 ultratome (Leica). The sections were mounted on nickel grids and processed for colloidal gold staining [38] as follows. The grids were incubated in $4 \%$ sodium metaperiodate solution (Sigma) to expose reactive antigens on bacterial surface [40]. Following multiple washes in water, the grids were incubated in $0.05 \mathrm{M}$ glycine (to inactivate any background reactive aldehyde groups) and blocked with 5\% Aurion bovine serum albumin in TBS, before floating them in goat anti-O157 (KPL) primary antibody diluted in TBS with $0.05 \%$ Tween 20 (TBS-T). After further washes with TBS-T, the slides were incubated with Aurion $10 \mathrm{~nm}$ gold labeled-rabbit anti-goat (diluted in TBS-T) secondary antibody. The grids were subsequently washed and counter-stained with uranyl acetate and Reynolds lead citrate using standard protocols $[39,41,42]$, before viewing on the electron microscope. All reagents used for TEM were obtained from Electron Microscopy Services (EMS), Hatfield, PA.

\section{Results and discussion}

The RAJ sections from both cattle exposed to $E$. coli O157 and those that were never exposed to E. coli O157 demonstrated the same histo-morphology as previously described $[30,33,43]$ and observed by analyzing tissue sections by light, fluorescence and transmission electron microscopy. Regardless of their age and breed, the RAJ was characterized by an abrupt replacement of columnar epithelial cells by stratified squamous epithelial cells (Figure 1). The site at which this histological change occurred was either characterized by deep grooves in some animals or had planar presentation in others. Irrespective of this, E. coli $\mathrm{O} 157$ when present interacted with the cells as described previously [33,34]. E. coli O157 formed microcolonies on the columnar epithelial cells, about 3$5 \mathrm{~cm}$ from the junction, and could often be associated with local microvilli effacement as well as pedestal formations extending from the columnar epithelial cell at the site of bacterial adherence (Figure 1). Conversely, E. coli $\mathrm{O} 157$ adherence to the squamous epithelial cells was diffuse, and the bacteria appeared to adhere directly to the cell surface or pedestal-like surface structures (Figure 1).

To ascertain if bison would have similar RAJ histomorphology as cattle, the bison and bovine RAJ was compared. As anticipated, based on the phylogenetic 

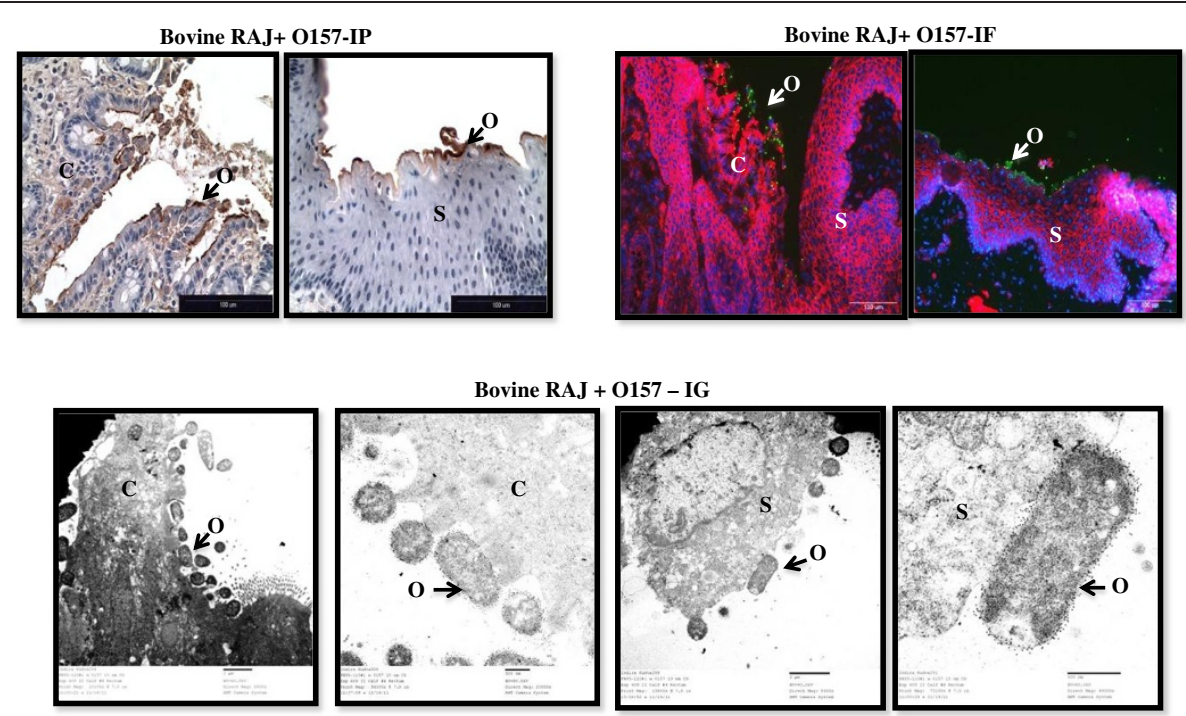

Figure $1 \mathrm{E}$. coli $\mathrm{O} 157$ adherence to squamous and columnar epithelium at the RAJ in experimentally inoculated E. coli O157-positive cattle. Immunoperoxidase (IP), immunofluorescence (IF) and immunogold (IG) labeled RAJ tissue sections are shown. In the IP stained sections (40x magnification), epithelial cells are blue and E. coli 0157, brown. In the IF stained sections (20x magnification), epithelial cells are orange-red with blue nuclei, and E. coli 0157 are green. IG micrographs are shown at 6800x, 23000x, 9300x, 49000x magnifications, respectively, with E. coli 0157 encased in $10 \mathrm{~nm}$ colloidal gold label. C, columnar epithelium; S, stratified squamous epithelium; O, E. coli O157. Arrows indicate examples of adhering E. coli 0157 .

relationship of these animals, the cellular architecture of both RAJs were similarly characterized with the columnar epithelial cell replacement by stratified squamous epithelial cells (Figure 2). Additionally, even the various epithelial cell markers that were tested demonstrated similar distribution (Figure 2). Villin, a structural protein component of the microvilli that comprise the brush borders [44], was restricted to the columnar epithelial cells in both tissue samples, although these were more intensely detected in the bovine RAJ. This protein confers plasticity to the brush borders through its interactions with and cleavage of F-actin, the filament protein $[44,45]$. Vimentin is an embryonic cytoskeleton filament protein involved in the intracellular transport of proteins
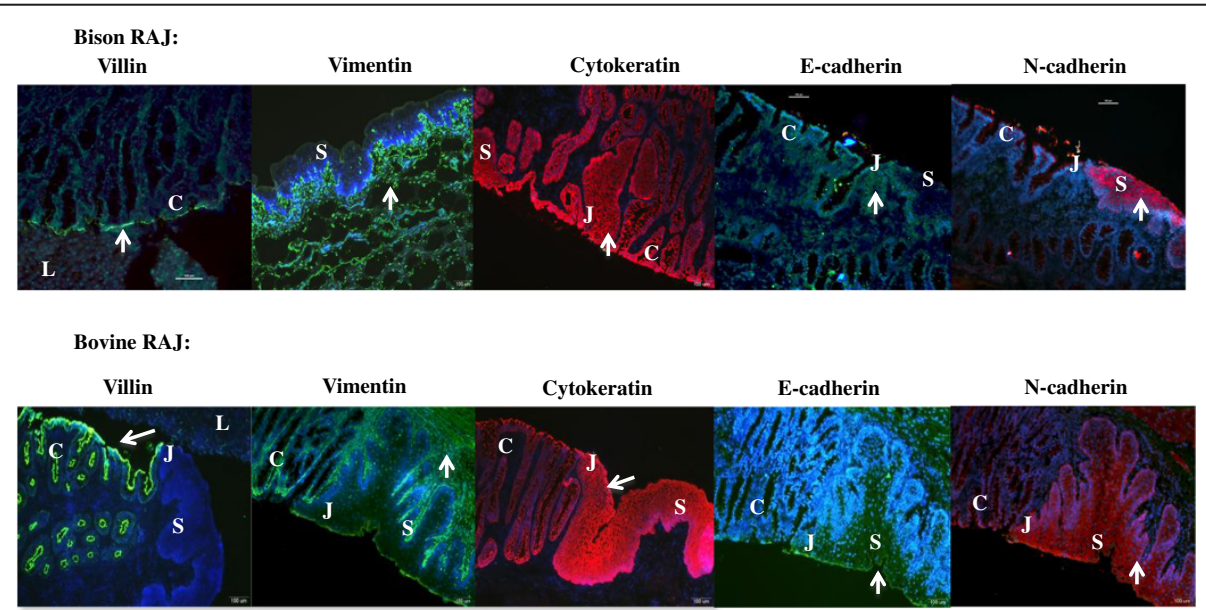

Figure 2 Comparative histo-morphologies of bison versus bovine RAJ from E. coli 0157-negative animals. Immunofluorescence stained slides are shown at 10x magnification. Different fluorescent tags were used to detect each epithelial cell protein: Villin (green), Vimentin (green), Cytokeratin (orange-red), E-cadherein (green) and N-cadherin (red). Epithelial cell nuclei have blue fluorescence. C, columnar epithelium; S, stratified squamous epithelium; J, junction between columnar and stratified squamous epithelium; L, liver tissue section used in sample preparation. Arrows indicate representative regions of stained epithelial cell proteins. 
between the nucleus and plasma membrane $[43,46]$. It continues to be expressed by fibroblasts lining the submucosa, occasional $M$ cells and carcinogenic cells in adult animals $[43,46]$. The protein was detected in the submucosal layers of both bison and bovine RAJ tissue sections (Figure 2). Cytokeratins are keratin containing structural proteins that extend like filaments from the surface of the nucleus to the cell membrane and contribute largely to maintaining cell-shape $[47,48]$. There are two types of cytokeratins, acidic and basic, which occur in pairs in an organ or tissue specific manner $[47,48]$. The anti-cytokeratin antibody (Table 1) preparation used in this study ensured targeting this wide range of cytokeratins that are common to all epithelial tissue [33,46-48]. Cytokeratins were found uniformly distributed in all epithelial cells comprising the RAJ of both animals (Figure 2). Cadherins comprise a superfamily of transmembrane glycoproteins involved in calcium mediated cell-cell adhesion and hence, tissue integrity [49]. Classical cadherins include epithelial-cadherin (E-cadherin), neural-cadherin (N-cadherin), placental-cadherin (P-cadherin) and vascular endothelial-cadherin (VE-cadherin). Since these cadherins appear to be broadly specific to cell-types, these proteins have also been associated with cell growth and tissue differentiation [49-52]. However, studies have reported a wider distribution of $\mathrm{N}$-cadherins in non-neural tissues, of both human and bovine origin, including the mouth, breast, heart, kidney, liver, endometrium, endothelium and tumors $[50,53,54]$. Here we observed that both E-cadherin and N-cadherin were co-localized to the epithelial cells lining the RAJ but interestingly, $\mathrm{N}$-cadherin was more abundant, especially with the squamous epithelial cells. Strong N-cadherin immunoreactivity has been associated with inflammed ileal tissues in cattle with Johne's disease, as also with proliferative epithelium lining the healthy endometrium $[50,53,54]$ and thus, the increased presence of $\mathrm{N}$-cadherin at the RAJ may be related to the relatively rapid turn-over/ growth of cells at this site. This distribution of E- and $\mathrm{N}$ - cadherins was similar to both bison and bovine RAJ tissue samples.

Since the bison and bovine RAJ presented several anatomical and cytological similarities, we evaluated the ability of E. coli O157 to adhere to bison RAJ cells. In our previous studies, we had standardized an in vitro E. coli $\mathrm{O} 157$ adherence assay using harvested bovine RAJ squamous epithelial (RSE) cells [33,34]. An in-depth analysis showed that this assay with bovine RSE cells successfully reproduced the $E$. coli $\mathrm{O} 157$ adherence patterns as seen in vivo on the RAJ of cattle infected with O157 (Figures 1, 3, 4). Hence, we extrapolated the assay to include bison RSE cells as a presumed reflection of $E$. coli O157-RAJ interactions in vivo in the bison. Both E. coli O157 strains (EDL 933 and 86-24 $\mathrm{Sm}^{\mathrm{R}}$ ) adhered to the bison RSE cells; the binding characteristics resembled those seen with bovine RSE cells (Figure 3; Table 2). Except for the E. coli $\mathrm{O} 157$ strain $86-24 \mathrm{Sm}^{\mathrm{R}}$ strain demonstrating diffuse, moderate adherence with bison RSE cells, E. coli
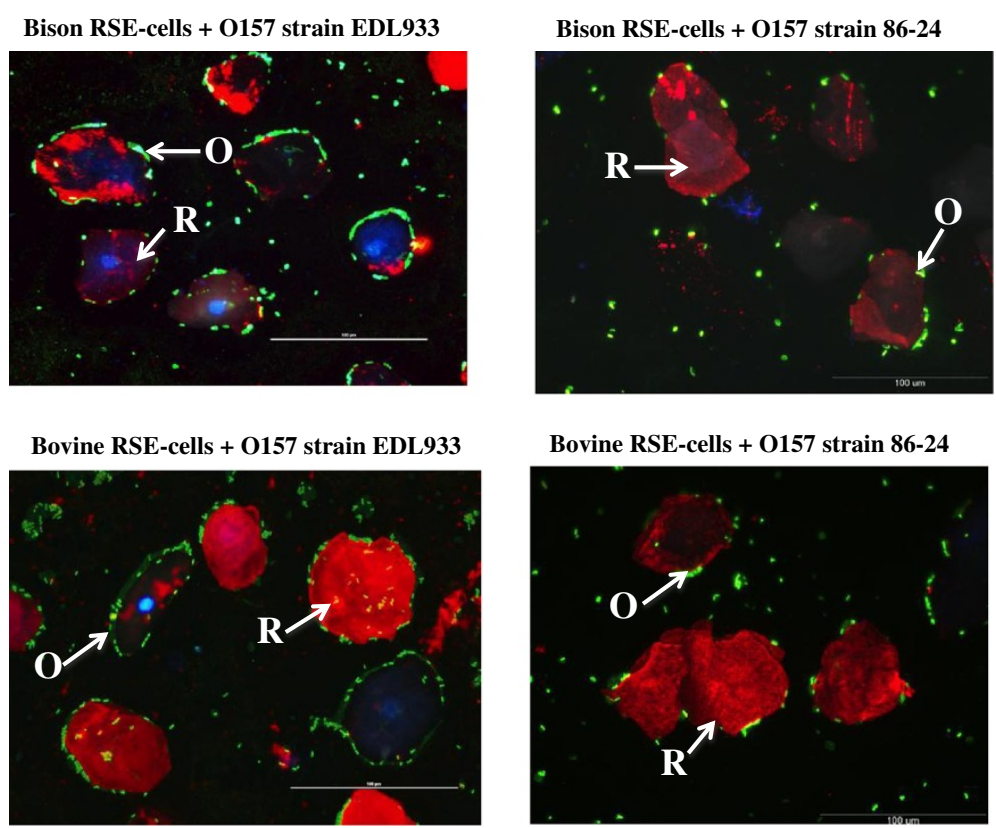

Figure 3 E. coli 0157 adherence patterns on bison and bovine RSE cells in the presence of D + Mannose. Immunofluorescence stained slides are shown at 40x magnification, with the RSE cells' cytokeratins having orange-red, their nuclei, blue and E. coli O157, green fluorescence. Arrows indicate R, RSE cells and O, E. coli O157. 


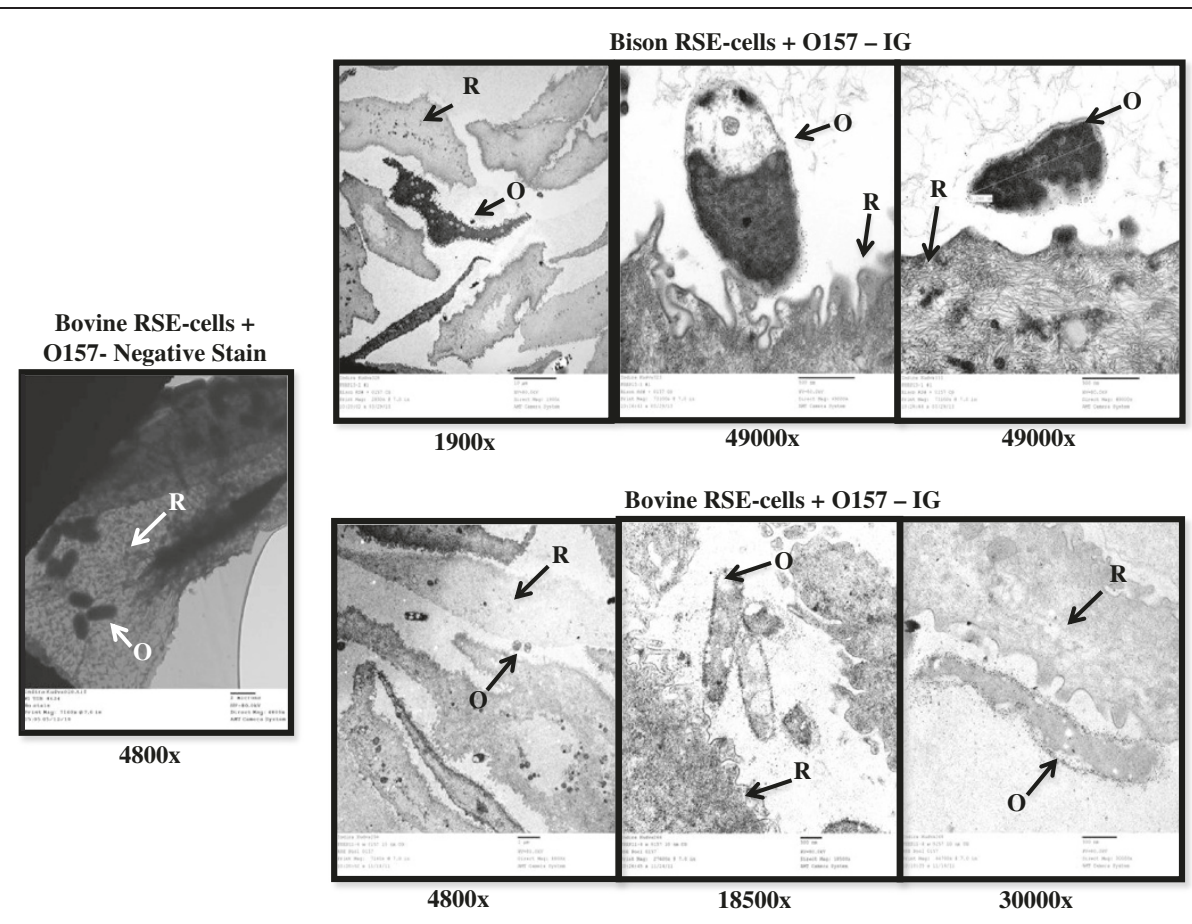

Figure 4 Transmission electron micrographs confirming E. coli 0157 adherence to bison and bovine RSE cells. A sample of negative stained grid and other immunogold labeled grids with RSE cells and adhering E. coli O157 are shown; magnifications used are below each micrograph. Arrows indicate R, RSE cells and O, E. coli O157.

O157 strain EDL 933 bound RSE cells from both species in an aggregative, moderate pattern (Table 2). E. coli $\mathrm{O} 157$ adherence to bison RSE cells was verified and compared to bovine RSE cells using fluorescent and transmission electron microscopy (Figures 3 and 4) further confirming the true adherence of $E$. coli $\mathrm{O} 157$ to these RSE cells.

\section{Conclusion}

Our study demonstrates that the bison RAJ shares histomorphological characteristics with the bovine RAJ. These overlapping features may have contributed to the ability of E. coli O157 to adhere to bison RSE cells, thus extending this utility of the RSE cell adherence assay

Table 2 Quantitation of bison and bovine RSE cells with adherent $E$. coli 0157 in the presence of D + mannose

\begin{tabular}{|c|c|c|c|c|c|c|c|}
\hline \multirow[t]{3}{*}{ Bacteria tested } & \multirow{3}{*}{$\begin{array}{l}\text { Bacterial adherence } \\
\text { pattern }\end{array}$} & \multicolumn{4}{|c|}{$\begin{array}{l}\text { Eukaryotic cells with adherent bacteria, in the ranges shown, } \\
\text { for two different trials }{ }^{1} \\
\left(\mathrm{MOI}^{2}=10^{6} \text { bacteria: } 10^{5} \text { cells }\right)\end{array}$} & \multirow{2}{*}{\multicolumn{2}{|c|}{$\begin{array}{l}\text { Percent Mean }+/- \text { standard } \\
\text { error of mean, of eukaryotic } \\
\text { cells with adherent bacteria } \\
\text { in the ranges shown }\end{array}$}} \\
\hline & & \multicolumn{2}{|c|}{ Trial I } & \multicolumn{2}{|c|}{ Trial II } & & \\
\hline & & $>10$ & $1-10^{(3)}$ & $>10$ & $1-10$ & $>10$ & $1-10$ \\
\hline \multirow{2}{*}{$\begin{array}{l}\text { Bison RSE cells + E. coli O157 } \\
\text { strain EDL } 933\end{array}$} & Aggregative, & 58 & 102 & 29 & 124 & \multirow{2}{*}{$27 \pm 9$} & \multirow{2}{*}{$71 \pm 7$} \\
\hline & Moderate & $(160)^{4}$ & $(160)$ & $(160)$ & (160) & & \\
\hline \multirow{2}{*}{$\begin{array}{l}\text { Bison RSE cells + E. coli O157 } \\
\text { strain 86-24 Sm }\end{array}$} & Diffuse, & 12 & 138 & 5 & 140 & \multirow{2}{*}{$5.5 \pm 2.5$} & \multirow{2}{*}{$93.5 \pm 3.5$} \\
\hline & Moderate & (153) & (153) & (145) & (145) & & \\
\hline \multirow{2}{*}{$\begin{array}{l}\text { Bovine RSE cells + E. coli O157 } \\
\text { strain EDL } 933\end{array}$} & Aggregative, & 52 & 92 & 18 & 135 & \multirow{2}{*}{$22 \pm 11$} & \multirow{2}{*}{$72 \pm 13$} \\
\hline & Moderate & (156) & (156) & (160) & (160) & & \\
\hline \multirow{2}{*}{$\begin{array}{l}\text { Bovine RSE cells + E. coli O157 } \\
\text { strain 86-24 Sm }\end{array}$} & Diffuse, & 104 & 53 & 106 & 28 & \multirow{2}{*}{$66.5 \pm 1.5$} & \multirow{2}{*}{$25.5 \pm 7.5$} \\
\hline & Strong & $(160)$ & (160) & (155) & (155) & & \\
\hline
\end{tabular}

${ }^{1}$ Each trial had one slide per bacterial group. Each slide in turn had 8 technical replicates (eight 2 spotted; 10-20 well-dispersed cells were evaluated per spot or chamber).

${ }^{2} \mathrm{MOI}$, multiplicity of infection.

${ }^{3}$ Number of bacteria adhering to each cell is shown as a range of $>10$, and $1-10$. Number of cells without bacteria is not shown

${ }^{4}$ Total number of cells evaluated in each trial is shown in parenthesis.

${ }^{5}$ Percent means for ranges used to determine "moderate or strong" adherence are in bold. 
for incorporation in bison studies. Given that $E$. coli O157 has been isolated from bison retail meat, $E$. coli O157-contaminated bison meat has been implicated in an outbreak and that E. coli $\mathrm{O} 157$ has been isolated from these animals, this study supports that bison can serve as reservoirs for E. coli $\mathrm{O} 157$ in the wild. Experimental studies in bison are being planned to determine whether E. coli O157-bison RSE cell interactions seen in vitro occur in vivo as well.

\section{Competing interests}

The authors declare that they have no competing interests.

\section{Author's contributions}

ITK was the project leader and designed, coordinated, conducted experiments, analyzed results, and drafted the manuscript. JAS assisted in design of experiments, data analysis, and contributed to the final draft of the manuscript. Both authors read and approved the final manuscript.

\section{Acknowledgements}

Excellent technical support provided by Mr. Bryan Wheeler, Dr. Rebecca Madison and the NADC animal caretakers is acknowledged. Thanks to Dr. Steven C. Olsen and Dr. Evelyn Dean-Nystrom for giving access to necropsy samples from bison and creating a collection of cattle tissue, respectively. We thank Dr. Brian Brunelle, and Dr. Mitchell Palmer for their insightful review of this manuscript.

\section{Disclaimer}

Mention of trade names or commercial products in this article is solely for the purpose of providing specific information and does not imply recommendation or endorsement by the U.S. Department of Agriculture. USDA is an equal opportunity provider and employer.

\section{Author details}

${ }^{1}$ Food Safety and Enteric Pathogens Research Unit, National Animal Disease Center, Agricultural Research Service, U.S. Department of Agriculture, Ames, IA 50010, USA. ${ }^{2}$ Microscopy Services Laboratory, National Animal Disease Center, Agricultural Research Service, U.S. Department of Agriculture, Ames, IA 50010, USA.

Received: 21 October 2013 Accepted: 18 December 2013

Published: 28 December 2013

\section{References}

1. Hedrick PW: Conservation genetics and North American bison (Bison bison). $J$ Hered 2009, 100:411-420.

2. Factsheets: American Bison. 2009. http://library.sandiegozoo.org/ factsheets/bison/bison.htm

3. Food Safety and Inspection Service (FSIS), Food Safety Fact Sheet: Bison from farm to Table. Washington, DC: United States Department of Agriculture; 2013.

4. Bibi F, Vrba ES: Unraveling bovin phylogeny: accomplishments and challenges. BMC Biol 2010, 8:50. doi:10.1186/1741-7007-8-50.

5. Stevens MG, Olsen SC, Cheville NF: Comparative effects of bovine cytokines on cattle and bison peripheral blood mononuclear cell proliferation. Comp Immun Microbiol Infect Dis 1997, 20:155-162.

6. Swain SD, Nelson LK, Hanson AJ, Siemsen DW, Quinn MT: Host defense function in neutrophils from the American bison (Bison bison). Comp Biochem Physiol A Mol Integr Physiol 2000, 127:237-247.

7. Mackintosh C, Haigh JC, Griffin F: Bacterial diseases of farmed deer and bison. Rev Sci Tech 2002, 21:249-263.

8. Miller RS, Sweeney SJ: Mycobacterium bovis (bovine tuberculosis) infection in North American wildlife: current status and opportunities for mitigation of risks of further infection in wildlife populations. Epidemiol Infect 2013, 141:1357-1370.

9. Pruvot M, Forde TL, Steele J, Kutz SJ, deBuck JD, van der Meer F, Orsel K: The modification and evaluation of an ELISA test for the surveillance of Mycobacterium avium subsp. paratuberculosis infection in wild ruminants. BMC Vet Res 2013, 9:5. doi: 10.1186/1746-6148-9-5.
10. Olsen SC: Brucellosis in the United States: role and significance of wildlife reservoirs. Vaccine 2010, 28S:F73-F76.

11. Jay-Russell MT, Langholz JA: Potential role of wildlife in pathogenic contamination of fresh produce. Humn-Wild Interact 2013, 7:140-157.

12. Woodbury MR, Chirino-Trejo M: A survey of the fecal bacteria of bison (Bison bison) for potential pathogens and antimicrobial susceptibility of bison-origin E. coli. Can Vet J 2011, 52:414-418.

13. Sánchez S, Martínez R, Rey J, García A, Blanco J, Blanco M, Blanco JE, Mora A, Herrera-León S, Echeita A, Alonso JM: Pheno-genotypic characterisation of Escherichia coli 0157:H7 isolates from domestic and wild ruminants. Vet Microbiol 2010, 142:445-449.

14. Ferens WA, Hovde CJ: Escherichia coli O157:H7: Animal Reservoir and Sources of Human Infection. Food Path Dis 2011, 8:465-486.

15. Osterholm MT: Foodborne disease in 2011 - The rest of the story. NEJM 2011, 364:889-891.

16. Scallan E, Hoekstra RM, Angulo FJ, Tauxe RV, Widdowson M, Roy SL, Jones JL, Griffin PM: Foodborne illness acquired in the United States - Major pathogens. Emerg Infect Dis 2011, 17:7-15.

17. Vital signs: Incidence and trends of infection with pathogens transmitted commonly through food -- Foodborne diseases active surveillance network, 10 U.S. Sites, 1996-2010. MMWR 2011, 60:749-755.

18. Griffin PM, Ostroff SM, Tauxe RV, Greene KD, Wells JG, Lewis JH, Blake PA: Illnesses associated with Escherichia coli 0157:H7 infections. A broad clinical spectrum. Ann Intern Med 1998, 109:705-712.

19. Kaper JB, O'Brien AD: Escherichia coli O157:H7 and other Shiga Toxin-Producing E. coli strains. Washington, D.C: ASM Press; 1998.

20. Gyles CL: Shiga toxin-producing Escherichia coli: an overview. J Anim Sci 2007, 85:E45-E62.

21. Buzby JC, Roberts T: The economics of enteric infections: human foodborne disease costs. Gastroenterol 2009, 136:1851-1862.

22. Batz MB, Hoffmann S, Morris JG: Ranking the disease burden of 14 pathogens in food sources in the United States using attribution data from outbreak investigations and expert elicitation. J Food Protect 2012, 75:1278-1291.

23. Hoffman S, Batz MB, Morris JG: Annual cost of illness and quality-adjusted life year losses in the United States due to 14 foodborne pathogens. J Food Protect 2012, 75:1292-1302.

24. Council of State and Territorial Epidemiologists (CSTE) Report: 13-ID-01: Update to Public Health Reporting for Shiga toxin-producing Escherichia coli (STEC). Atlanta, Georgia: CSTE; 2013.

25. Li Q, Sherwood JS, Logue CM: The prevalence of Listeria, Salmonella, Escherichia coli and E. coli 0157:H7 on bison carcasses during processing. Food Microbiol 2004, 21:791-799.

26. Magwedere K, Dang HA, Mills EW, Cutter CN, Roberts EL, DebRoy C: Incidence of Shiga toxin-producing Escherichia coli strains in beef, pork, chicken, deer, boar, bison, and rabbit retail meat. J Vet Diagn Invest 2013 25:254-258.

27. Food Safety and Inspection Service (FSIS), Food Safety Fact Recall Release: FSIS-RC-043-2010: Colorado firm recalls bison products due to possible E. coli 0157:H7 contamination. Washington, DC: United States Department of Agriculture; 2010.

28. Reinstein S, Fox JT, Shi X, Alam MJ, Nagaraja TG: Prevalence of Escherichia coli 0157:H7 in the American bison (Bison bison). J Food Protect 2007, 70:2555-2560

29. Li Q, Sherwood JS, Logue CM: The growth and survival of Escherichia coli 0157:H7 on minced bison and pieces of bison meat stored at $5^{\circ} \mathrm{C}$ and $10^{\circ} \mathrm{C}$. Food Microbiol 2005, 23:415-421.

30. Quantrell RJO, Naylor SW, Roe AJ, Spears K, Gally DL: EHEC 0157:H7-getting to the bottom of the burger bug. Microbiol Today 2004, 31:126-128.

31. Sheng H, Lim JY, Knecht HJ, Li J, Hovde CJ: Role of Escherichia coli 0157: $\mathrm{H} 7$ virulence factors in colonization at the bovine terminal rectal mucosa. Infect Immun 2006, 74:4685-4693.

32. Dean-Nystrom EA, Stoffregen WC, Bosworth BT, Moon HW, Pohlenz JF: Early attachment sites for Shiga-toxigenic Escherichia coli 0157:H7 in experimentally inoculated weaned calves. Appl Environ Microbiol 2008, 74:6378-6384

33. Kudva IT, Dean-Nystrom E: Bovine recto-anal junction squamous epithelial (RSE) cell adhesion assay for studying Escherichia coli 0157 adherence. J App Microbiol 2011, 111:1283-1294.

34. Kudva IT, Griffin RW, Krastins B, Sarracino DA, Calderwood SB, John M: Proteins other than the locus of enterocyte effacement-encoded 
proteins contribute to Escherichia coli 0157:H7 adherence to bovine rectoanal junction stratified squamous epithelial cells. BMC Microbiol 2012, 12:103.

35. Fischer AH, Jacobson KA, Rose J, Zeller R: Cryosectioning tissues. Cold Spring Harb Protoc 2008, 3(8). doi: 10.1101/pdb.prot4991.

36. Shi SR, Key ME, Kalra KL: Antigen retrieval in formalin-fixed, paraffin-embedded tissues: an enhancement method for immunohistochemical staining based on microwave oven heating of tissue Sections. J Histochem Cytochem 1991, 39:741.

37. McDowell EM: Fixation and processing. In Diagnostic Electron Microscopy. 1st edition. Edited by Jones RT, Trump BF. Somerset, NJ: John Wiley and Sons; 1978:130.

38. Knutton S: Electron microscopical methods in adhesion. In Adhesion of microbial pathogens. Edited by Doyle RJ, Ofek I. San Diego, CA: Academic Press; 1995:145-158

39. Hayat MA, Miller SE: Negative staining. New York: McGraw-Hill Publishing Co; 1990

40. Skepper JN, Powell JM: Microscopy (TEM)- immunogold staining of epoxy resin sections for transmission electron. Cold Spring Harb Protoc 2008, 3(6). doi: 10.1101/pdb.prot5015.

41. Dawes CJ: Biological techniques in electron microscopy. New York: Barnes and Noble; 1971.

42. Pease DC: Histology techniques for electron microscopy. New York: Academic Press; 1964.

43. Mahajan A, Naylor S, Mills AD, Low JC, Mackellar A, Hoey DEE, Currie CG, Gally DL, Huntley J, Smith DGE: Phenotypic and functional characterization of follicle-associated epithelium of rectal lymphoid tissue. Cell Tissue Res 2005, 321:365-374.

44. Kanaya T, Aso H, Miyazawa K, Kido T, Minashima T, Watanabe K, Ohwada S, Kitazawa H, Rose MT, Yamaguchi T: Staining patterns for actin and villin distinguish $\mathrm{M}$ cells in bovine follicle-associated epithelium. Res Vet Sci 2007, 82:141-149.

45. Bretscher A, Weber K: Villin is a major protein of the microvillus cytoskeleton, which binds both $\mathrm{G}$ - and F-actinin a calcium-dependent manner. Cell 1980, 20:839-847.

46. Rusu D, Loret S, Peulen O, Mainil J, Dandrifosse G: Immunochemical, biomolecular and biochemical characterization of bovine epithelia intestinal primocultures. BMC Cell Biol 2005, 6:42. doi:10.1186/1471-2121-6-42.

47. Moll R, Franke WW, Schiller DL: The catalog of human cytokeratins: Patterns of expression in normal epithelia, tumors and cultured cells. Cell 1982, 31:11-24.

48. Heid HW, Moll I, Franke WW: Patterns of expression of trichocytic and epithelial cytokeratins in mammalian tissues II. Concomitant and mutually exclusive synthesis of trichocytic and epithelial cytokeratins in diverse human and bovine tissues (hair follicle, nail bed and matrix, lingual papilla, thymic reticulum). Differentiation 1988, 37:215-230.

49. Angst BD, Marcozzi C, Magee Al: The cadherin superfamily: diversity in form and function. Cell Sci 2001, 114:629-641.

50. Liaw CW, Cannon C, Power MD, Kiboneka PK, Rubin LL: Identification and cloning of two species of cadherins in bovine endothelial cells. EMBO J 1990, 9:2701-2708

51. Lewis JE, Wahl JK III, Sass KM, Jensen PJ, Johnson KR, Wheelock MJ: Cross-talk between adherens junctions and desmosomes depends on plakoglobin. J Cell Biol 1997, 136:919-934

52. Kantak SS, Kramer RH: E-cadherin regulates anchorage-independent growth and survival in oral squamous cell carcinoma cells. J Biol Chem 1998, 273:16953-16961.

53. Aho AD, McNulty AM, Coussens PM: Enhanced expression of interleukin-1a and tumor necrosis factor receptor-associated protein 1 in ileal tissues of cattle infected with Mycobacterium avium subsp. Paratuberculosis. Infect Immun 2003, 71:6479-6486

54. Tsuchiya B, Sato Y, Kameya T, Okayasu I, Mukai K: Differential expression of $\mathrm{N}$-cadherin and E-cadherin in normal human tissues. Arch Histol Cytol 2006, 69:135-145.

doi:10.1186/1746-6148-9-266

Cite this article as: Kudva and Stasko: Bison and bovine rectoanal junctions exhibit similar cellular architecture and Escherichia coli 0157 adherence patterns. BMC Veterinary Research 2013 9:266.

\section{Submit your next manuscript to BioMed Central and take full advantage of:}

- Convenient online submission

- Thorough peer review

- No space constraints or color figure charges

- Immediate publication on acceptance

- Inclusion in PubMed, CAS, Scopus and Google Scholar

- Research which is freely available for redistribution 